\title{
O CONHECIMENTO A PRIORI DA IDEIA DE DEUS
}

Guilherme Diniz da Silva*

Resumo: Na filosofia de Descartes, a ideia de Deus tem um papel determinante para a constituição do sistema epistemológico, devido fundamentalmente à necessidade da atemporalidade das verdades compreendidas pelo cogito. Ao intui uma segunda evidência, a primeira é remetida para a memória, levando assim à perda de sua atualidade. Somente uma realidade atemporal pode garantir a presença das verdades que o raciocínio precisa interligar para formar o conhecimento. Contudo, sem o conhecimento da natureza dessa garantia, ou seja, sem o conhecimento da essência divina, não seria possível sustentar a coerência da filosofia cartesiana, ao pretender embasar as ciências sobre a metafísica. Por isso, Descartes precisa mostrar que a ideia de Deus é cognoscível. Mas, como seria possível conhecer a essência de Deus, sendo o cogito uma realidade intelectualmente finita?

Palavras-chave: realidade formal, essência, ideia, Deus, conhecimento.

Descartes pretende nas Meditações Metafísicas levar a dúvida metódica até o seu limite, duvidando não só de todas as suas opiniões, mas até mesmo do corpo próprio e dos raciocínios matemáticos ${ }^{1}$. Contudo, ao levar a efeito essa intenção, a ação do pensamento, enquanto duvida de todas as coisas, não pode deixar de existir, ou ser falsa. Pelo menos uma coisa é certa: o cogito ${ }^{2}$. Não obstante, a verdade do pensamento é temporal, ou seja, somente é real durante o tempo em que é autorrepresentada. Ao considerar outros conteúdos de representação, a verdade de si, primeiramente compreendida, deixa de ser verdadeira. Por isso, há a necessidade de um fator mais eminente do que o cogito para garantir a estabilidade da verdade ${ }^{3}$.

Esse fator se apresenta sob a forma da ideia de Deus. A partir dos princípios de causalidade e correspondência ${ }^{4}$ (o nada não é causa de alguma coisa e o menos perfeito não é causa do mais perfeito) foi possível desenvolver as provas a posteriori ${ }^{5}$ da existência de Deus. Ao demonstrar que a realidade objetiva ${ }^{6}$ do ser perfeito e infinito exige uma causa perfeita e infinita, Descartes pretendeu

\footnotetext{
* Faculdade de São Bento (São Paulo - SP). Graduação com bolsa de Iniciação Científica concedida pela FAPESP. Orientação: Franklin Leopoldo e Silva. E-mail pessoal: guilherme.diniz.op@hotmail.com

${ }^{1} \mathrm{AT}, \mathrm{IX}, 13$.

${ }^{2} \mathrm{AT}, \mathrm{IX}, 19$.

${ }^{3}$ LANDIM FILHO, 1992, p. 112 passim.

${ }^{4} \mathrm{AT}, \mathrm{IX}, 32$.

${ }^{5}$ AT, IX, 36.

${ }^{6}$ AT, IX, 32.
} 
afirmar que esta causa é a própria realidade formal ${ }^{7}$ de Deus. Uma vez que o cogito não é capaz de engendrar a ideia de Deus, é preciso concluir que há uma causa não menos divina para ela. A tarefa do pensamento destina-se agora para a possibilidade de compreensão da garantia da verdade, isto é, da essência divina.

Quais são as condições de possibilidade da apreensão da essência divina? A resposta a essa pergunta encontra-se na prova a priori $i^{8}$ da existência de Deus, visto que a natureza dessa demonstração tem como ponto de partida a própria essência divina. Na prova a priori, a ideia de "ser sumamente perfeito" ${ }^{\prime \prime}$ implica a existência necessária, haja vista que a existência, ou substância, é uma perfeição. A finalidade desse raciocínio é revelar a relação necessária entre veracidade e existência. Noutros termos, é preciso comprovar que a realidade formal de Deus (essência divina) é conforme a realidade formal da ideia de Deus (imagem verdadeira da essência divina).

Mesmo não tendo existência fora do pensamento, várias realidades formais continuam sendo verdadeiras (o caso da ideia de triângulo é paradigmático). Pois, toda realidade formal é per se nota, isto é, a realidade e a evidência são inerente uma a outra (se a evidência é verdadeira, a fortiori o verdadeiro é real). Porém, as realidades formais são evidentes ainda que não haja existência além do pensamento nem dependência com este (as realidades formais podem existir somente no pensamento e serem, ao mesmo tempo, independentes do pensamento). A razão disso deve-se à essência determinada (autoconstituição da realidade formal a partir da evidência). Toda realidade formal traz consigo a impossibilidade de invenção noemática. Por isso, a verdade dessas ideias só poderia provir da realidade formal de Deus. Assim, também na prova a priori, deve-se dizer que Deus é criador de sua própria ideia.

Partido do princípio de que a evidência confere a significação da verdade, não seria em vão observar que a evidência da ideia de Deus é a condição para o conhecimento a priori da verdade divina. Com efeito, o conhecimento a priori se exprime através da ideia per se nota, sobrelevando-se ao conhecimento a posteriori das provas pelos efeitos. Por isso, a ideia per se nota de Deus deve permitir a completa apreensão da realidade divina, uma vez que a amplitude exigida não é inferior à intelecção da essência de Deus.

Contudo, como é possível conhecer a Deus a partir de sua realidade formal? Como pode o finito conhecer o infinito? Na verdade, o infinito só pode ser entendido (intelligere), nunca compreendido (comprehendere) ${ }^{10}$. Enquanto que a compreensão orienta-se para a delimitação conceitual, a intelecção limita-se apenas a tangenciar nocionalmente. Por isso, pode-se conhecer a Deus sem compreendê-lo conceitualmente. Pois, o conhecimento de Deus é antes o resultado da percepção do que da predicação. Uma vez que os atributos são conteúdos acidentais relativos à vontade do sujeito e as propriedades, conteúdos essenciais, independentes de qualquer volição, a predicação de atributos divinos não seria considerável; ao contrário, somente a percepção de propriedades divinas teria status cognitivo. Uma vez admitido que as propriedades divinas são realidades formais, é preciso concluir que a ideia de Deus é incompreensível, na medida em que é inteligível (o conhecimento a priori de Deus é uma "incompreensão positiva"). Isso significa que Deus

\footnotetext{
${ }^{7}$ GUEROULT, 1968, p. 172-173.

${ }^{8}$ AT, IX, 52.

${ }^{9} \mathrm{AT}, \mathrm{IX}, 52$.

${ }^{10}$ BEYSSADE, 2009, p. 236.
} 
é, ao mesmo tempo, perfeito e infinito (inteligível e incompreensível) ${ }^{11}$. Somente o Ser enquanto unidade de perfeições poderia realizar a síntese do inteligível com o incompreensível. Contudo, vale salientar que Deus não é incompreensível em si, e sim que o cogito não pode esgotar a compreensão do infinito através de um conceito. A incompreensão positiva é na verdade uma compreensão finita do infinito.

Em suma, a ciência perfeita ${ }^{12}$ (universali Sapientia) ${ }^{13}$ depende da estabilidade da verdade, garantida por Deus. Para o sistema se completar, é preciso conhecer a natureza da garantia atemporal das verdades que formam o tecido dessa ciência. Contudo, o conhecimento a priori da garantia divina é paradoxalmente uma incompreensão positiva. Isso significa que o conceito tem sua origem na verdade, mas nem por isso se pode compreender conceitualmente a verdade. A legitimidade da ciência perfeita (conceito do verdadeiro) não exige, como se poderia pressupor, o conhecimento perfeito (conceito da verdade) ${ }^{14}$. Somente Deus poderia conhecer perfeitamente (conhecimento adequado). O cogito, ao desfrutar da intuição intelectual (intuitus mentis) ${ }^{15}$ e da dedução lógica (deductio ou inductio) ${ }^{16}$, somente pode empreender uma ciência perfeita (concepção adequada $)^{17}$. Por isso, o conhecimento a priori de Deus é uma intuição per speculum ${ }^{18}$. Enquanto que a intuição implica uma inteligibilidade, o raciocínio leva à impossibilidade da redução conceitual. Com razão, a essência divina deve ser apreendida de modo imediato e reflexivo, pois o conhecimento $a$ priori de Deus é uma reflexão da ideia inata de Deus (construção indutiva a partir da experiência interna do cogito ao meditar a ideia de Deus) ${ }^{19}$.

\section{Referências}

Principal

1. DESCARTES, R. CEuvres de Descartes. 11 vols. Publiées par Charles Adam et Paul Tannery. Paris: Vrin, 1996.

Secundária

\footnotetext{
${ }^{11}$ BEYSSADE, 2009, p. 237-238.

${ }^{12} \mathrm{AT}, \mathrm{IX}, 56$.

${ }^{13} \mathrm{AT}, \mathrm{X}, 360,19-20$.

${ }^{14}$ DEVILLAIRS, 2004, p. 135.

${ }^{15}$ AT, X, 400, 21.

${ }^{16}$ AT, X, 400, 22-23.

${ }^{17} \mathrm{AT}, \mathrm{IX}, 48$.

${ }^{18}$ DEVILLAIRS, 2004, p. 131.

${ }^{19}$ BEYSSADE, 2009, p. 231-232.
} 
2. BEYSSADE, J.-M. A ideia de Deus e as provas de sua existência. In: COTTINGHAM, J. (org.). Descartes. Aparecida: Ideias \& Letras, 2009, p. 213-241.

3. DEVILLAIRS, L. Descartes et la connaissance de Dieu. Paris: Vrin, 2004.

4. GUEROULT, M. Descartes selon l'ordre des raisons. 2 vols. Paris: Aubier, 1992.

5. LANDIM FILHO, R. Evidência e verdade no sistema cartesiano. São Paulo: Loyola, 1998. 